\title{
Ecdysis as an auxiliary route for the removal of heavy metals in crustaceans: Laboratory analysis with native mangrove specimens
}

Rômulo José Ramos ( $\nabla$ ramosjromulo@yahoo.com.br)

Vila Velha University: Universidade Vila Velha https://orcid.org/0000-0003-0335-1749

Gustavo Leite

Federal University of Espirito Santo: Universidade Federal do Espirito Santo

\section{Research Article}

Keywords: Minuca burgersi, pollution, estuarine, metals, exoskeletons

Posted Date: March 22nd, 2021

DOl: https://doi.org/10.21203/rs.3.rs-341317/v1

License: (c) (1) This work is licensed under a Creative Commons Attribution 4.0 International License.

Read Full License 


\section{Abstract}

Fiddler crabs (Minuca burgersi) were kept under controlled conditions in an experimental laboratory to assess their ability to secrete metallic contaminants by ecdysis. They were fed different copper $(\mathrm{Cu})$ and lead $(\mathrm{Pb})$ concentrations, with subsequent measurement of heavy metals concentration in the released and renewed exoskeletons. Our results show that these crabs can purify both metals during ecdysis, demonstrating to be an efficient way to decontaminate these toxic components, besides accrediting this native species as a strong indicator of contamination in estuarine environments. Our results also reinforce the need for attention to the contamination characterization in crustaceans before and after ecdysis to avoid underestimation.

\section{Introduction}

Different studies in ecotoxicology, which use reference specimens to measure contaminants concentrations in different environments, have been described for years. The use of these reference specimens, which are generally not native to the environment, can generate underestimated responses to contamination's real impact. Therefore, recent publications advocate using native species for such measurements since toxicological responses may more accurately reflect environmental conditions (Do Hong et al. 2004; Takenaka et al. 2006, 2007; Okumura et al.2007).

Among the different types of contaminants of anthropic origin, metallic compounds cause concern worldwide since they cause profound adverse effects on the organisms of the most diverse ecosystems and human populations (Ramos et al. 2010; Vilhena et al. 2013).

Among these ecosystems, the estuarine environment is one of the most contaminated by metallic compounds, which seriously affect the physiology of the organisms exposed to these contaminants (Capparelli et al. 2017; Portner 2010; Veríssimo et al. 2013). Organisms, such as crustaceans, exposed for a long time to these metallic contaminants, when they survive, end up accumulating them directly or indirectly through contact with contaminated water, substrate, and food intake (Boyd 2010; Oliveira et al. 2013; Rumisha et al. 2017). As the bioaccumulation process is continuous, this will provide the absorption of heavy metals by different tissues of native crustaceans, accrediting them to sensitive indicators of environmental degradation (Bergey \& Weis 2007; Kannan et al. 2016; Capparelli et al. 2016, 2017)

However, these species have detoxification mechanisms to deal with these contaminants, such as the production of metal granules linked to metallothionein, performed by the hepatopancreas, or the secretion of metal salts by osmosis made by the gills (Capparelli et al. 2017; Martins et al. 2011; Mazzei et al. 2014; Pinheiro et al. 2012).

Although less studied, another way for crustaceans to contain and reduce the bioaccumulation process by heavy metals is through the exchange of their exoskeleton (ecdysis). This mechanism proved to be efficient and essential for the detoxification process because it occurs frequently and naturally, in which 
exoskeletons containing a portion of the contaminants end up being discarded in the environment during the growth of the animal. Through the process of ecdysis, a portion of the contaminants present in the hemolymph ends up migrating to the exoskeleton, providing for its elimination when discarded (Bergey \& Weis 2007).

However, establishing baseline metal contamination levels in studies with specimens collected directly from the natural environment is challenging to measure. Therefore, experimental studies where the native crustaceans samples are kept in laboratory conditions free from contamination by metals before evaluating their secretion capacity are necessary. Therefore, under such controlled experimental conditions, we quantify the elimination of metallic contaminants, copper, and lead, from the ecdysis process, in native specimens typical of estuarine ecosystems, Minuca burgersi (Holthuis 1967).

Under controlled laboratory conditions, we seek to demonstrate that heavy metals' clearance on crustaceans occurs at specific time intervals linked to ecdysis processes. In this way, it would be possible to establish a more precise sampling protocol for these organisms to ascertain the environment's real degradation rates in the event of impacts with metallic contaminants.

\section{Methods}

\subsection{Animal acclimatization}

In this experiment, 36 adult male guitarist crabs of the species Minuca burgersi (Holthuis 1967), with carapace ranging from 18 to $20 \mathrm{~mm}$, were used. These animals were collected in the Lameirão mangrove, located in the city of Vitória, Espírito Santo, Brazil (20¹7 '0.27"S and $\left.40^{\circ} 18^{\prime} 20.87^{\prime \prime} 0\right)$.

These crustaceans were equally divided into six acrylic containers with $27,000 \mathrm{~cm}^{3}$ containing sand sediment and partially immersed in $24 \%$ o saltwater, forming six groups (Fig. 1).

After testing with different food offerings, e.g., mangrove plant leaves, shrimp, and fruit pieces, the pineapple, without heavy metal contamination, was selected as a nutritional source in the whole experiment due to better acceptance by the crustaceans.

These individuals were kept in these conditions for 90 days for acclimatization and to allow the animals to perform ecdysis to release the exoskeletons formed in the natural environment, ensuring that the next exoskeleton contained the smallest possible traces of contaminants acquired in the natural environment. It is worth mentioning that under laboratory conditions, the average ecdysis time was three months.

\subsection{Crab contamination procedure and arrangement of experimental groups}

For food contamination, we follow indications of works published by Overnell \& Trewhella (1979) and Overnell (1984), where $5 \mathrm{mg}$ of $\mathrm{CuSO}_{4} \cdot 5 \mathrm{H}_{2} \mathrm{O}$ and $10 \mathrm{mg}$ of salts $\mathrm{Pb}\left(\mathrm{NO}_{3}\right)_{2}$ (Sigma-Aldrich Inc., USA) were 
added to each gram of pineapple, reaching Cu concentrations between 3.2 to $5.9 \mathrm{mg}$ and $\mathrm{Pb}$ concentrations between 2.0 to $8.0 \mathrm{mg}$, per gram of pineapple.

Three groups were established. Group A was fed daily with pineapple without contamination by metals, and the other two groups fed daily with contaminated amounts of pineapple until reaching the daily concentration of $5 \mathrm{mg} / \mathrm{g}$ (Group B) and $10 \mathrm{mg} / \mathrm{g}$ (Group C).

After the ecdysis was carried out in the acclimatization period, the crabs were fed, as already mentioned, until they carried out the first ecdysis, approximately 30 days after the experiment began. The exoskeletons were preserved for the later analysis, being considered as a released exoskeleton.

After the first molting, all groups' crabs started to receive uncontaminated pineapple until the next ecdysis occurred, which also occurred approximately 30 days after the beginning of this second nutrition procedure, whose exoskeletons were also preserved for later analysis and were considered as a renewed exoskeleton.

The exoskeleton samples were dried for three days at $60^{\circ} \mathrm{C}$, with subsequent grinding, $1 \mathrm{~g}$ of each crushed sample was digested in a 3:1 acid solution of $\mathrm{HCl}+\mathrm{HNO}_{3}$ (both from Sigma-Aldrich Inc., USA). These samples were then kept at $60^{\circ} \mathrm{C}$ for $48 \mathrm{~h}$, filtered through $0.45 \mu \mathrm{m}$ filters (Analítica Ltd., Brazil), $\mathrm{Cu}$ and $\mathrm{Pb}$ measurements were present in the samples. They were evaluated by atomic absorption spectrometry as previously described (Carvalho et al. 1991), using the ICE 3000 atomic absorption spectrometer (Thermo Scientific Inc., USA). All data are presented in $\mu \mathrm{g} / \mathrm{g}$ of dry exoskeleton. Our measurements were validated after analysis of certified samples (Table 1) obtained from Mytilus edulis tissue (ERMCE-278K) and estuarine sediment (BCR-667), both purchased from Sigma-Aldrich Inc., USA. Whose research inputs were partially financed by the "Espírito Santo Research and Innovation Support Foundation", FAPES (grant n ${ }^{\circ}$ 0461/2015), and "Coordination for the Improvement of Higher Education Personnel", CAPES.

Table 1

Recovery percentages of certified reference material. $\mathrm{Cu}=$ copper; $\mathrm{Pb}=$ lead

\begin{tabular}{|c|c|c|c|c|c|c|}
\hline \multirow[t]{2}{*}{ Reference material } & \multicolumn{2}{|c|}{ Reference values (mg. $\mathrm{kg}^{-1}$ ) } & \multicolumn{2}{|c|}{ Found values $\left(\mathrm{mg} \cdot \mathrm{kg}^{-1}\right)$} & \multicolumn{2}{|c|}{ Recovery (\%) } \\
\hline & {$[\mathrm{Cu}]$} & {$[\mathrm{Pb}]$} & [Cu] & {$[\mathrm{Pb}]$} & {$[\mathrm{Cu}]$} & {$[\mathrm{Pb}]$} \\
\hline Mytilus edulis & 6.0 & 2.2 & 6.50 & 1.9 & 108.7 & 90.6 \\
\hline Estuarine sediment & 60.0 & 31.9 & 55.6 & 26.4 & 92.6 & 82.6 \\
\hline \multicolumn{7}{|c|}{$\begin{array}{l}\text { Certified samples of Mytilus edulis fabric (ERMCE-278K) and estuarine sediment (BCR-667), both } \\
\text { purchased from Sigma-Aldrich Inc., USA, were used as reference material for measuring the amounts } \\
\text { of copper }(\mathrm{Cu}) \text { and lead }(\mathrm{Pb}) \text {. The results in } \mathrm{mg} \cdot \mathrm{kg}^{-1} \text { were converted to the percentage recovery of the } \\
\text { reference material. }\end{array}$} \\
\hline
\end{tabular}

\subsection{Statistical analysis}


Independent samples Student's t-tests were used to verify statistically significant differences in Cu and $\mathrm{Pb}$ concentrations before and after the ecdysis. Six analyzes were applied, one for each element ( $\mathrm{Cu}$ and $\mathrm{Pb})$ and group $(\mathrm{A}, \mathrm{B}$, and $\mathrm{C})$. Before applying the t-tests, the assumptions of normality and homoscedasticity of the data were checked by Shapiro-Wilk and Levene tests, respectively. If the normality assumption were violated, the non-parametric Mann-Whitney $U$ test would be used; and if the normality assumption was not violated, but that of homoscedasticity was, we would use the t-test with Welch's correction. All analysis and graphics were performed at GraphPad Prism software, 5.0 version (GraphPad Software Inc., USA).

\section{Results And Discussion}

The fiddler crabs Minuca burgersi is a crustacean from the intertidal region with wide distribution, occurring in the Western Atlantic of the USA (south of Florida), Mexico to Brazil, and all the Caribbean islands (Thurman et al. 2013). This species inhabits and eats organic debris associated with surrounding sediments, in addition to being considered an ecosystem engineer due to his high bioturbation skills at the sediment-water interface, which also modifies the availability of resources and pollutants such as trace elements (Pillon et al. 2019).

Due to its wide distribution, ease of sampling, high capacity for population recovery, and laboratory management, in addition to the extensive literature on its biological and ecological characteristics, it becomes an adequate bioindicator for these countries.

At the end of the experiment, we verified that there was a reduction, but not significant, in the concentrations of $\mathrm{Cu}$ or $\mathrm{Pb}$ between the exoskeletons released and renewed in Group $\mathrm{A}$, without contamination, whose average concentrations of $\mathrm{Cu}$ and $\mathrm{Pb}$ whose variations were $14.72 \mu \mathrm{g} / \mathrm{g}$ and 0.12 $\mu \mathrm{g} / \mathrm{g}$, respectively (Fig. 2A, Table 2). 
Table 2

Statistical tests results. Independent samples Student's t-tests were used to verify statistically significant differences in $\mathrm{Cu}$ and $\mathrm{Pb}$ concentrations before and after the ecdysis. Six analyzes were applied, one for each element ( $\mathrm{Cu}$ and $\mathrm{Pb}$ ) and group $(\mathrm{A}, \mathrm{B}$, and $\mathrm{C})$.

\begin{tabular}{|c|c|c|c|c|c|c|}
\hline & \multicolumn{2}{|c|}{$\begin{array}{l}\text { Shapiro-Wilk } \\
\text { normality test }\end{array}$} & \multicolumn{2}{|c|}{$\begin{array}{l}\text { Levene's homogeneity } \\
\text { of variances test }\end{array}$} & \multicolumn{2}{|c|}{$\begin{array}{l}\text { Independent samples } \\
\text { Student t-test }\end{array}$} \\
\hline & W & $\mathbf{p}$ & $\mathbf{F}$ & $\mathbf{p}$ & $t$ & $\mathrm{p}$ \\
\hline Group A - Cu (0 mg/g) & 0.95 & 0.229 & 5.06 & 0.035 & 1.67 & 0.109 \\
\hline Group B - Cu (5 mg/g) & 0.96 & 0.361 & 1.12 & 0.301 & 3.66 & $0.001^{a}$ \\
\hline Group C - Cu (10 mg/g) & 0.96 & 0.519 & 13.33 & $0.001^{a, c}$ & 6.71 & $0.000^{b}$ \\
\hline Group A - Pb (0 mg/g) & 0.96 & 0.430 & 0.00 & 0.977 & 0.24 & 0.809 \\
\hline Group B - Pb (5 mg/g) & 0.92 & 0.071 & 1.19 & 0.286 & 5.44 & $0.000^{b}$ \\
\hline Group C - Pb (10 mg/g) & 0.96 & 0.359 & 0.00 & 0.967 & 3.60 & $0.002^{\mathrm{a}}$ \\
\hline
\end{tabular}

When we evaluated the crabs present in Group B and Group C, we found a significant reduction in the average concentrations of $\mathrm{Cu}$ and $\mathrm{Pb}$ in the released and renewed exoskeletons, whose variations were $22.05 \mu \mathrm{g} / \mathrm{g}$ and $3.09 \mu \mathrm{g} / \mathrm{g}$, with $5 \mathrm{mg} / \mathrm{g}$ concentration metals in the food, and $80.89 \mu \mathrm{g} / \mathrm{g}$ and $2.12 \mu \mathrm{g} / \mathrm{g}$, with $10 \mathrm{mg} / \mathrm{g}$ concentration metals in the food, respectively (Figs. 2B and 2C, Table 2).

Interestingly, in the renewed exoskeletons of Group B crabs, we found lower levels of concentration of $\mathrm{Cu}$ and $\mathrm{Pb}$ than renewed exoskeletons in Group $\mathrm{A}$ (Figs. 2A and 2B). This indicates that when offering foods containing intermediate concentrations of metals, complementary detoxification processes must have been triggered, such as the action of the hepatopancreas and gills, leading to a lesser migration of metals from the hemolymph to the exoskeleton, leaving a smaller portion of heavy metals available for adsorption in the exoskeleton of this group.

According to Pytharopoulou et al. (2008), Lemus et al. (2016), and Capparelli et al. (2018), metalloneins and similar proteins that bind to metals rich in low molecular weight cysteines are found in increased levels in the digestive gland, hepatopancreas, and gills of marine crustaceans exposed to environmental conditions contaminated with heavy metals, being essential for the pathways of trace elements in the metabolism and sequestration of metals. Thus, they act in the process of bioaccumulation of toxic metals, detoxification, homeostatic regulation of metals, protection against oxidative stress, among others.

It is worth mentioning that some studies have discussed the use of these proteins as specific metallic biomarkers because they are also related to other environmental variations, such as salinity, sex, stages, 
body size, seasonality, and tissues (Morgan et al. 2004; Ladhar-Chaabouni et al. 2011; Cenov et al. 2018). However, because it is a controlled experiment, this analysis bias can be discarded in our interpretations.

By doubling the concentration of metals in the food, doses of $\mathrm{Cu}$, and $\mathrm{Pb}$ in Group C, with $10 \mathrm{mg} / \mathrm{g}$, we found that the metals' migration behavior from the hemolymph released to the exoskeleton occurred differently (Fig. 2C). For $\mathrm{Cu}$, the concentration in this exoskeleton more than doubled in relation to Group $\mathrm{B}$, while for $\mathrm{Pb}$, the concentrations were equivalent. This result may be related to the existence of greater affinity of this metal for the tissues that form the exoskeleton in the stiffening mechanisms during ecdysis, or even the greater availability of $\mathrm{Cu}$ in the hemolymph, despite the same concentration of $\mathrm{Cu}$ and $\mathrm{Pb}$ in the food offered. Several authors, e.g., Rainbow (2002); Kouba et al. (2010); Stanek et al. (2014), reported in their studies that $\mathrm{Cu}$ is a component of the respiratory system of crustaceans, forming hemocyanin, causing high concentrations of this metal to exist in their hemolymph when compared to other metals. Thus, it is assumed that there is a greater tendency for the occurrence of a simple migration/diffusion to the tissues that form the exoskeleton.

Despite the difference in the accumulation of metals in the released exoskeleton, it was noticed that the mechanisms of elimination of these toxic components were activated in a similar way to that observed for Group B, generating concentrations of these metals in the renewed exoskeletons, which are also equivalent.

In this way, it can be inferred that different $\mathrm{Cu}$ and $\mathrm{Pb}$ concentrations do not interfere with the normal clearance physiology of these animals for clearance (Figs.

$2 B$ and $2 \mathrm{C}$ ).

These results indicate that ecdysis is one of the physiological processes by which this species of crustacean purges $\mathrm{Cu}$ and $\mathrm{Pb}$ concentrations (Fig. 2B and 2C). In agreement with our findings, other authors have described that the mobilization of $\mathrm{Cu}$ in the exoskeletons of Minuca rapax (other species related to the Fiddler crabs) for the hemolymph is dynamic, occurring whenever the animal needs this metal (Capparelli et al. 2017). For Pb, it was previously described that Minuca pugnax raised in environments with high $\mathrm{Pb}$ concentrations eliminated $\mathrm{Pb}$ by ecdysis, while the same species of crab raised in low concentrations of $\mathrm{Pb}$ absorbed it in soft tissues (Bergey \& Weis 2007). Ramos et al. (2021) also characterized the process of detoxifying heavy metals in Ucides cordatus crabs in natura during the period of ecdysis, demonstrating to be an important detoxification route in these invertebrates.

The molecular mechanisms involved in these clearings are unknown, but it was observed that two intracellular enzymes, protein kinase $\mathrm{C}$ (PKC) and phosphodiesterase (PDE), were always activated when the crabs were exposed to high concentrations of $\mathrm{Cu}$ and $\mathrm{Pb}$; high production of $\mathrm{PKC}$ and PDE, and in turn, stimulates the increase of ecdysteroids in the pre-ecdysis phase, which finally stimulates ecdysis (Spaziani et al. 2001).

This work differs from previous studies in that we conducted a controlled experiment in the laboratory, where the dosage of the metallic contaminant could be pre-established and the food removed after 
ecdysis (Fig. 2B and 2C). Since these animals can re-accumulate these metals due to their ethological behavior (White and Rainbow, 1986), ecdysis in the $\mathrm{Cu}$ and $\mathrm{Pb}$ purge can be more accurately quantified by controlling other external parameters. This sensitivity is necessary since the renewed exoskeletons' levels of contamination were practically the same observed in renewed exoskeletons of animals fed without contaminated food (Fig. $2 \mathrm{~B}$ and $2 \mathrm{C}$ vs. $2 \mathrm{~A}$ ).

\section{Conclusions}

Our results indicate that studies with crustaceans to measure the environmental impact in degraded areas must consider the complex physiological and ecological dynamics involved in the biology of the population of native organisms. Also, in ecosystems that continuously receive metallic contaminants, crustaceans can be used at any time of the year because their exoskeletons retain traces of metal.

However, in isolated cases of contamination, e.g., rupture of mining dams, or accidental discharge of effluents with metallic contaminants, the use of crustacean exoskeletons to assess the environmental impact should be performed before ecdysis periods, avoiding underestimation of results and misjudgment of the true environmental impact.

Finally, the use of exoskeleton released in ecdysis as an environmental marker allows the assessment of the degree of contamination of the organism without the need for sacrifice, allowing its reintroduction to its natural environment and minimizing the ecological footprint left by this type of monitoring, then that would be extremely important for studies with endangered species.

\section{References}

1. Bergey LL, Weis JS (2007) Molting as a mechanism of depuration of metals in the fiddler crab, Uca pugnax. Marine Environmental Research 64(5):556-562. doi:10.1016/j.marenvres.2007.04.009

2. Boyd RS (2010) Heavy Metal Pollutants and Chemical Ecology: Exploring New Frontiers. J Chem Ecol 36(1):46-58. doi:10.1007/s10886-009-9730-5

3. Capparelli MV, Abessa DM, McNamara JC Effects of metal contamination in situ on osmoregulation and oxygen consumption in the mudflat fiddler crab Uca rapax (Ocypodidae, Brachyura).

Comparative Biochemistry and Physiology Part C: Toxicology \& Pharmacology, 186 185- 186(1), 102-111. doi:10.1016/j.cbpc.2016.03.004 (2016)

4. Capparelli MV, McNamara JC, Grosell M Effects of waterborne copper delivered under two different exposure and salinity regimes on osmotic and ionic regulation in the mudflat fiddler crab, Minuca rapax (Ocypodidae, Brachyura). Ecotoxicol Environ Saf, 190 143, 201-209.

doi:10.1016/j.ecoenv.2017.05.042 (2017)

5. Capparelli MV, Gusso-Choueri PK, de Souza Abessa DM, McNamara JC (2018) Seasonal environmental parameters influence biochemical responses of the fiddler crab Minuca rapax to 
contamination in situ. Comp Biochem Physiol Part C 216:93-100.

doi.org/10.1016/j.cbpc.2018.11.012

6. Carvalho CEV, Lacerda LD, Gomes MP (1991) Heavy metal contamination of the marine biota along the Rio de Janeiro coast, SE-Brazil. Water Air Soil Pollution 57-58(1):645-193 653. doi:10.1007/BF00282928

7. Cenov A, Perić L, Glad M, Žurga P, Lušić DV, Traven L, Bihari, N A baseline study of the metallothioneins content in digestive gland of the Norway lobster Nephrops norvegicus from Northern Adriatic Sea: body size, season, gender and metal specific variability. Mar Pollut Bull 131:95-105. https://doi.org/10.1016/j.marpolbul.2018. 03.002 (2018)

8. Do Hong LC, Becker-Van Slooten K, Tarradellas J (2004) Tropical ecotoxicity testing with Ceriodaphnia cornuta. Environ Toxicol 19:497-504

9. Kannan N, Thirunavukkarasu N, Suresh A, Rajagopal K Analysis of Heavy Metals Accumulation in Mangroves and Associated mangroves Species of Ennore Mangrove Ecosystem, East Coast India. Indian Journal of Science Technology, 9(46). doi:10.17485/ijst/2016/v9i46/101551 (2016)

10. Kouba A, Buřič M, Kozák P (2010) Bioaccumulation and effects of heavy metals in crayfish: a review. Water Air Soil Pollut 211:5-16 doi.10.1007 / s11270-009-0273-8

11. Ladhar-Chaabouni R, Machreki-Ajmi M, Hamza-Chaffai A (2011) Use of metallothioneins as biomarkers for environmental quality assessment in the Gulf of Gabès (Tunisia). Environ Monitor Assess 184(4):2177-2192. https://doi.org/10.1007/s10661-011-2108-5

12. Lemus M, Salazar R, Lapo B, Chung K (2016) Metalotioneínas en bivalvos marinos. Lat Am J Aquat Res 44(2):202-215. doi. org/10.3856/vol44-issue2-fulltext-2

13. Martins CMG, Almeida DV, Marins LFF, Bianchini A (2011) mRNA Expression and activity of iontransporting proteins in gills of the blue crab Callinectes sapidus: Effects of waterborne copper. Environ Toxicol Chem 30(1):206-211. doi:10.1002/etc.370

14. Mazzei V, Longo G, Brundo MV, Sinatra F, Copat C, Conti O, G., \& Ferrante M (2014) Bioaccumulation of cadmium and lead and its effects on hepatopancreas morphology in three terrestrial isopod crustacean species. Ecotoxicol Environ Saf 110:269-279. doi:10.1016/j.ecoenv.2014.09.015

15. Morgan AJ, Stürzenbaum SR, Winters C, Grime GW, Aziz NAA, Kille P (2004) Differential metallothionein expression in earthworm (Lumbricus rubellus) tissues. Ecotox Environ Safe 57(1):11-19. https://doi.org/10.1016/j.ecoenv.2003.08.022

16. Okumura DT, Sotero-Santos RB, Takenaka RA, Rocha O. Evaluation of cyanobacteria toxicity in tropical reservoirs using crude extracts bioassay with cladocerans. Ecotoxicology 16:263-270. doi.10.1007/s10646-006-0126-9 (2007)

17. Oliveira PJA, Coelho PA, Castiglioni D da S. Population biology of Ucides cordatus (Linnaeus, 1763) (Crustacea, Brachyura, Ucididae) from two tropical mangrove sites in northeast coast of Brazil. PanAmerican Journal of Aquatic Sciences, 8(2), 89-103 (2013)

18. Overnell J, Trewhella E (1979) Evidence for the natural occurance of (cadmium, copper)metallothionein in the crab Cancer pagurus. Comparative Biochemistry Physiology Part C: 
Comparative Pharmacology 64(1):69-76. doi:10.1016/0306-4492(79)90030-3

19. Overnell J (1984) The partition of copper and cadmium between different charge-forms of metallothionein in the digestive tubules of the crab, Cancer pagurus. Comparative Biochemistry Physiology Part C: Comparative Pharmacology 77(2):237-243. doi:10.1016/0742-212 8413(84)90007-0

20. Pillon CF, Gonçalves AS, Santos S, Castiglioni DS (2019) Composition and diversity of crabs (Decapoda, Brachyura) of brazilian northeast mangrove. Journal of Integrated Coastal Zone Management/Revista de Gestão Costeira Integrada 19(1):27-41. doi:10.5894/rgci-n212

21. Pinheiro MAA, Silva PPG, e, Duarte LF, de A, Almeida, A. A., \& Zanotto FP (2012) Accumulation of six metals in the mangrove crab Ucides cordatus (Crustacea: Ucididae) and its food source, the red mangrove Rhizophora mangle (Angiosperma: Rhizophoraceae). Ecotoxicol Environ Saf 81:114-121. doi:10.1016/j.ecoenv.2012.05.004

22. Pytharopoulou S, Sazakli E, Grintzalis K, Georgiou CD, Leotsinidis M, Kalpaxis DL Translational responses of Mytilus galloprovincialis to environmental pollution: integrating the responses to oxidative stress and other biomarker responses into a general stress index. Aquat Toxicol 89(1):1827. doi.org/ 10.1016/j.aquatox.2008.05.013 (2008)

23. Portner $\mathrm{H}-\mathrm{O}$ Oxygen- and capacity-limitation of thermal tolerance: a matrix for integrating climaterelated stressor effects in marine ecosystems. Journal of Experimental Biology, 213(6), 881-893. doi.10.1242/jeb.037523 (2010)

24. Rainbow PS (2002) Trace metal concentrations in aquatic invertebrates: why and so what? Environ Pollut 120:497-507. doi.org/10.1016/S0269-7491(02)00238-5

25. Ramos RJ, Travassos MP, Leite GR (2010) Characterization of macrofauna associated with articulated calcareous algae (Corallinaceae, rhodophyta) occurring in a hydrodynamic gradient on the Espírito Santo state coast, brazil. Braz J Oceanogr 58(4):275-285. doi:10.1590/S167987592010000400003

26. Ramos RJ, Tadokoro CE, de Carvalho Gomes $L$ et al (2021) Efficiency in heavy metal purge in crustaceans during the ecdysis. Environ Dev Sustain. https://doi.org/10.1007/s10668-021-01277-4

27. Rumisha $C$, Leermakers $M$, Mdegela RH, Kochzius $M$, Elskens $M$ Bioaccumulation and public health implications of trace metals in edible tissues of the crustaceans Scylla serrata and Penaeus monodon from the Tanzanian coast. Environmental Monitoring and Assessment, 230 189(10), 529. doi:10.1007/s10661-017-6248-0 (2017)

28. Spaziani E, Jegla TC, Wang WL, Booth JA, Connolly SM, Conrad CC et al (2001) Further Studies on Signaling Pathways for Ecdysteroidogenesis in Crustacean Y-Organs. Am Zool 41(3):418-429. doi:10.1093/icb/41.3.418

29. Stanek M, Dabrowski J, Dlugosz J, Janicki B (2014) Impact of the anthropogenisation on the metals bioaccumulation and distribution in the Spiny-Cheek Crayfish (Orconectes limosus Raf.) from Lake Gaplo, Poland. Int J Environ Res 8:1315-1322 Doi.10.1007 / s00128-017-2098-2 
30. Takenaka RA, Sotero-Santos RMB, Rocha $O$ Water quality assessment by ecotoxicological and limnological methods in water supplies, Southeast Brazil. Ecotoxicology, 15:73-82. doi.10.1007 / s10646-005-0048-y (2006)

31. Takenaka RA, Dellamano-Oliveira MJ, Rocha O Toxicidade de Extratos de Florações de Cianobactérias de Reservatórios do Rio Tietê, SP, aos Dafinídeos Ceriodaphnia dubia e Ceriodaphnia silvestrii (Cladocera, Crustacea). J Braz Soc Ecotox 2:147-156. doi. 10.5132 / jbse.2007.02.007 (2007)

32. Thurman CL, Faria SC, McNamara JC (2013) The distribution of fiddler crabs (Uca) along the coast of Brazil: implications for biogeography of the western Atlantic Ocean. Marine Biodiversity Records 6(e1):1-21. doi.org/10.1017/S1755267212000942

33. Veríssimo H, Lane M, Patrício J, Gamito S, Marques JC (2013) Trends in water quality and subtidal benthic communities in a temperate estuary: Is the response to restoration efforts hidden by climate variability and the Estuarine Quality Paradox? Ecol Ind 24:56-67. doi:10.1016/j.ecolind.2012.05.028

34. Vilhena MSP, Costa ML, Berredo JF (2013) Accumulation and transfer of Hg, As, Se, and other metals in the sediment-vegetation-crab-human food chain in the coastal zone of the northern Brazilian state of Para (Amazonia). Environ Geochem Health 35(4):241 477-494. doi:10.1007/s10653-013-9509-z

35. White S, Rainbow P (1986) Accumulation of cadmium by Palaemon elegans (Crustacea: Decapoda). Mar Ecol Prog Ser 32(3):17-25. doi:10.3354/meps032017

\section{Figures}

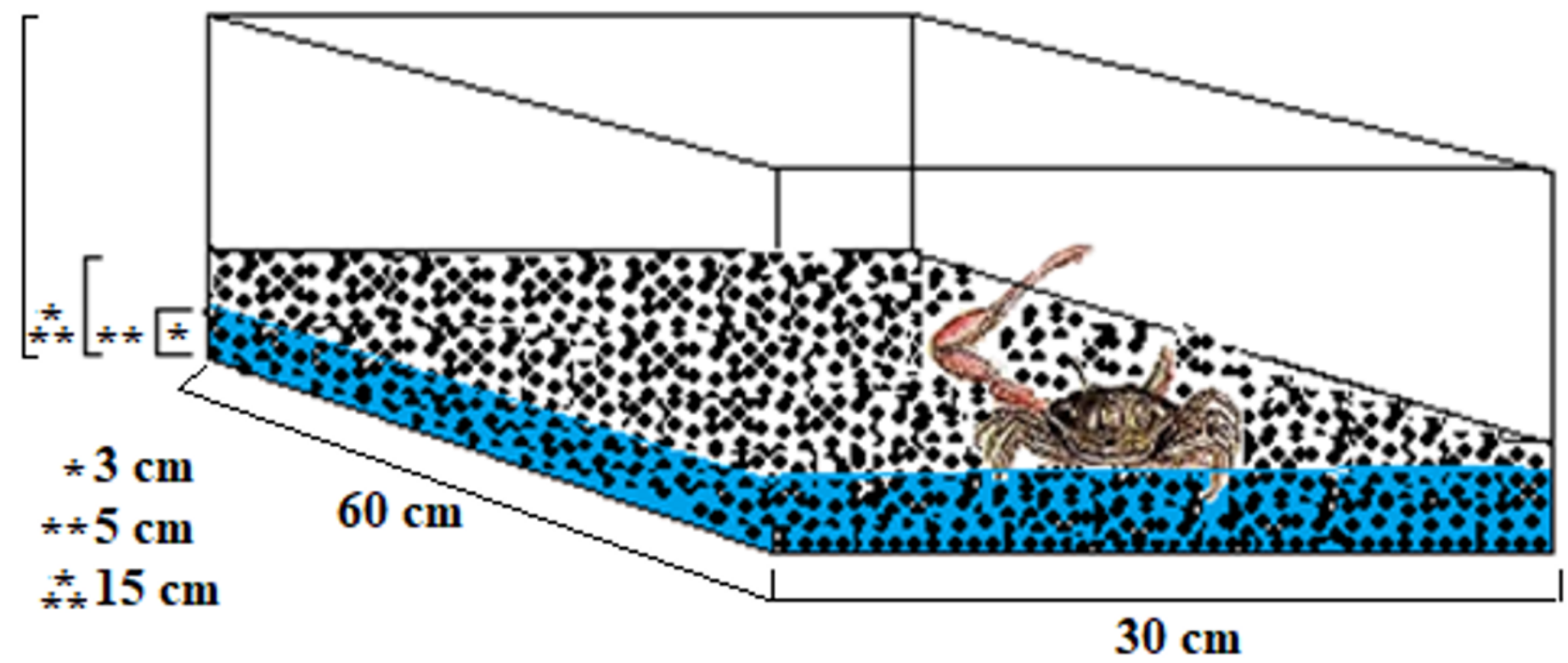

Figure 1

Acclimatization container for crustaceans $(27,000 \mathrm{~cm} 3)$. * height of the saline water layer $(24 \%)$; ** height of the sandy sediment; $* \star \star$ maximum height of the container. 


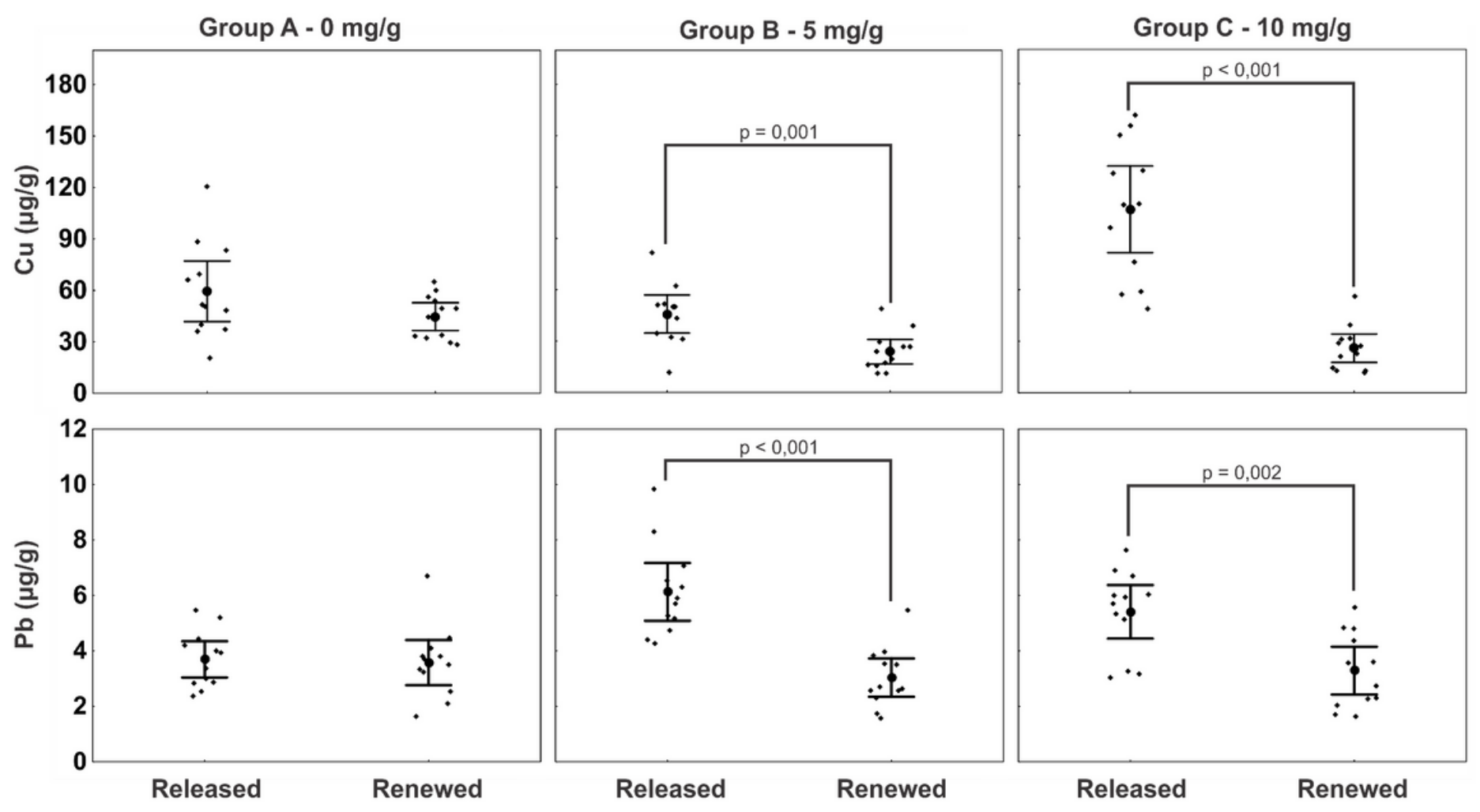

Figure 2

Concentrations of the metals $\mathrm{Cu}$ and $\mathrm{Pb}$ through ecdysis by the fiddler crabs $\mathrm{M}$. burgersi. Each point represents an individual value for each crustacean. The full circle represents the mean $\pm 95 \%$ confidence interval of all crabs' metal concentrations in each group. 